\title{
Why do we need a new Journal of European Consumer and Market Law?
}

\author{
Verica Trstenjak
}

(C) Springer-Verlag 2012

"Consumers by definition, include us all. They are the largest economic group, affecting and affected by almost every public and private economic decision. Yet they are the only important group... whose views are often not heard."

(John F. Kennedy)

In the Greek and Roman mythology, the protection of traders, travellers and shepherds rested on the Gods Hermes and Mercury. In this way, the well-being of the entrepreneurs was from a mythological point of view taken care of at the best. For their antipode, the consumer, however no specific God was responsible in the ancient Olympus. Today, it is self-evident that a special protection appertains not only to the entrepreneurs, but also and in particular to the consumer. For this, a new God was not required. We have, metaphorically speaking, climbed down from the heights of Olympus and we endeavour, at the level of the European Union and at the national level, to establish a balance of forces between the consumer and the entrepreneurs. Hermes and Mercury have served their time, and legal structures have taken their position: the legislators, the judiciary and the administrative authorities, supported by consumer organisations.

What role can in this context be played by journals of consumer law and in particular by the new Journal of European Consumer and Market Law? Is there really a need for a new Journal of European Consumer and Market Law in spite of the numerous journals, already devoted to European Law?

The views expressed in this article are personal views of the author only and do not represent the views of the Court of Justice of the European Union (CJEU).

Prof. Dr. Verica Trstenjak $(\bowtie)$

Advocate General, Court of Justice of the European Union, Luxemburg

E-Mail: <verica.trstenjak@curia.europa.eu>
The latter question is undoubtedly to be answered in the affirmative. For the consumer law of the European Union, which affects and regulates the behaviour of both consumers and entrepreneurs, raises a multitude of complex questions that need to undergo a thorough jurisprudential handling. Here, a new Journal of European Consumer and Market Law can make an important contribution by providing jurisprudentially based analyses and solution proposals.

The need for journals, devoted to European consumer law, is inseparably connected with the complexity of the hierarchy of norms in this field of law. Consumer law has indeed in some important areas been harmonised through directives, but in other areas it is still largely subject to the national regulation alone. In the areas where harmonisation has been undertaken, distinction must be made between minimum and full harmonisation, with a considerable margin of discretion available to Member States in case of a minimum harmonisation.

Beside this complexity of the hierarchy of consumer law norms within the European Union, the purchasing, travelling and other consumer customs are also changing. For the consumer today is no longer a classic consumer at the counter of his home village. He does not purchase just any DVD or CD, but rather attempts to find favourable possibilities on the internet (e.g. by downloading). However, an entrepreneur too is no longer a classic entrepreneur. $\mathrm{He}$ as well attempts to find new sales channels, among others also via internet. Development of information technologies plays an important factor in this context. More and more contracts are concluded online, which raises a multitude of new legal questions in various areas that range from the right of withdrawal, determination of jurisdiction in case of contracts concluded online, to the questions of credit card payment protection in such contracts. The use of the internet and other information technologies by consumers leads to 
new questions of intellectual property rights (e.g. violations of intellectual property in case of downloading) or of data protection (e.g. access to the personal data of the internet user) finding their way into consumer law protection cases, increasing thereby their complexity.

In addition, European consumer law is a fast moving area of law, which requires a constant jurisprudential analysis and handling of the newest developments. The two big projects, in which the institutions of the European Union have succeeded last year, are representative of the pace with which radical changes can be achieved in this area. The Proposal for a Directive of the European Parliament and of the Council on Consumer Rights, which was confirmed by the Council on 10.10.2011 and which repeals the Doorstep Selling Directive 85/577/EEC and the Distance Selling Directive 97/7/EC, represents an important step towards a full harmonisation in important areas of European consumer law. Regardless of the numerous critiques that have already been expressed and of those that are yet to be, this Directive shows a way to simpler cross-border legal relations. Likewise, on 11.10.2011, the European Commission adopted a Proposal for a Regulation on a Common European Sales Law, which aims at launching an optional contract regulation, valid throughout the European Union. In the coming months, Member States will have the possibility to decide upon the further bloom of this project, which in my opinion can offer a future basis for a better consumer protection as well as for a broader range of options available to the entrepreneurs. This Journal deals with these questions already in its first issue.

The role of the CJEU in the further development of the European consumer law should not be underestimated, since many preliminary ruling procedures concern this area. In this area of law, the CJEU takes care of a uniform interpretation of European Union law, thereby shaping the substance of European Union consumer law rules. In addition to the already mentioned new legal issues, which are related to the online purchase contracts and to the respective rights of entrepreneurs and consumers (e.g. the right of withdrawal and thereto related rights of the seller in the case Messner C-489/07, as well as the question of jurisdiction in joined case Pammer and Alpenhof C-585/08 and C-144/09), the judgements of CJEU have a considerable impact on national legislation as well as on legal practice within Member States. The area of guarantees, associated with consumer goods (e.g. case Quelle C-404/06, which even led to an amendment of the Civil Code - Bürgerliches Gesetzbuch - in Germany), and the obligation of a seller to remove the defective goods and install the replacements (joined cases Weber and Putz C-65/09 and C-87/09) should be recalled in this context; Editors' remark: discussed in this issue. The far reaching consequences of case-law of the CJEU are confirmed also by its case-law line regarding the role of national courts within the consumer protection procedures, which was introduced by judgement in joined cases Océano Grupo C-240/98 to C-244/98 and has reached its peak for the time being in the case Pénzügyi C-137/08. The latter case imposes on the national courts an obligation to investigate of their own motion whether a term conferring exclusive territorial jurisdiction in a contract is possibly an unfair one. At the moment, the CJEU is dealing with a question of what role the consumer organisations should play and whether, and if so, to what extent an actio popularis of such organisations should be allowed.

A further area, in which the co-creative role of the CJEU is portrayed, relates to the legal protection of air passengers. In addition to the rights, which are clearly conferred to the air passengers under the Air Passengers Rights Regulation 261/2004/EC in case of a cancellation of a flight, according to the judgements of CJEU in joined cases Sturgeon et al C-402/07 and C-432/07 a compensation can be required also in case of a flight delay. A newer judgement from 13.10.2011 in the case of Rodríguez et al C- $83 / 10$ confers to air passengers also a possibility of compensation for damages, arising from breach of a contract of carriage by air, including for non-material damages. Further developments in this area are to be expected.

These and other questions and issues pave the way, in which the new Journal of European Consumer and Market Law can grow and blossom. The new Journal should thereby not only be informative, but should above all offer a place for further academic discussions and opinion confrontation, as well as for proposals for solutions to various problems. May it be a place of development of new ideas, of proposals for amendments of the current legal position, of possible critiques, support and praise of valid legal acts, judgements of the CJEU and the opinions of its advocates generals!

The question that will always arise in this context is that of an appropriate balance between the protection of consumer interests and those of the entrepreneurs. For the maxim in dubio pro consumente cannot be given an unlimited validity. Rather, we must strive for a just equilibrium between the entrepreneurs on the one hand and the consumers on the other. By adding a word component "Market" in the title of this Journal, this ambition was given consideration to also by its editors, emphasizing thereby the requirement of a balanced regard to the interests of both protagonists of the business life. Not only in the area of tension among the conflicting legal positions, but also between the national and EU law and the legal assessment of further technological developments, the material needed to be commented upon will exist in abundance.

After all this, the question to be posed at the occasion of emergence of the new Journal of European Consumer and Market law is in my opinion not why we need this Journal, but why it has not emerged already before.

Therefore, I wish the new Journal vivat, crescat, floreat! 